\title{
AUTONOMIA E FINANCIAMENTO DAS IFES: DESAFIOS E AÇÕES ${ }^{1}$
}

\author{
Nelson Cardoso AmaraL*
}

Recebido: 06 de junho de 2008 Aprovado em: 03 de outubro de 2008

\begin{abstract}
*Dr. em Educação pela UNIMEP e Prof. do Instituto de Física e do Programa de Pós-Graduação em Educação da UFG.

Endereço: Rua T-47, 111, Apto. 701, St. Oeste, 74140-120, Goiânia-Go.

E-mail: nelsonamaral@cultura.com.br

Resumo: Este estudo tem como objetivo discutir o processo de autonomia e financiamento das Instituições Federais de Ensino Superior (IFES) nos últimos anos, sobretudo no período 1995-2006, abrangendo todo o governo de Fernando Henrique Cardoso e o primeiro mandato do governo de Luiz Inácio Lula da Silva. São analisadas as origens do financiamento das IFES, o caminho percorrido pelas propostas para se definir a autonomia das instituições, os limites impostos pela desigualdade social à expansão do setor privado, as fontes de financiamento da educação superior, os desafios existentes neste campo, e examina, ainda, possíveis ações a serem implementadas neste importante conjunto de instituições que desempenha um papel fundamental para a correção das desigualdades regionais brasileiras.
\end{abstract}

Palavras-chave: Autonomia. Financiamento. Educação superior. Expansão. Desigualdade social.

\section{AUTONOMY AND FINANCING OF THE FEDERAL HIGHER EDUCATION INSTITUTIONS: CHALLENGES AND ACTIONS}

\begin{abstract}
The purpose of this study is to dicuss the autonomy and financing process of the Federal Higher Education Institutions (IFES) in recent years, especially in the period 1995-2006, which comprises Fernando Henrique Cardoso's two governments and Luiz Inácio Lula da Silva's first government. It analyzes the origins of the IFES financing, the paths followed by the proposals to define the autonomy of the institutions, the limits imposed by social inequality on the expansion of the private sector, the financing sources of higher education, the existing challenges in this field, and the possible actions to be implemented in this important set of institutions that play a fundamental role in correcting Brazilian regional inequalities.
\end{abstract}

Key words: Autonomy. Financing. Higher education. Expansion. Social inequality.

\section{Introdução}

O Grupo Assessor em Educação, do Diretor Geral da UNESCO, integrado por especialistas das diversas regiões do mundo, identificou, em 1995, grandes temas de debate sobre a educação superior, no final do século XX. Os tópicos levantados pelo Grupo Assessor foram os seguintes: o papel das ciências humanas na discussão dos rumos da sociedade; integração entre o ensino e a

1 Apresentado no I Fórum Sobre as IFES: o TCU promove a busca de soluções, promovido pelo Tribunal de Contas da União (TCU) e Associação Nacional de Dirigentes das IFES (ANDIFES), realizado em Brasília nos dias 27 e 28 de novembro de 2007. Os anais do Fórum foram publicados pelo TCU em maio de 2008. 
pesquisa; democratização; qualidade; diversificação; relações com o setor produtivo; educação continuada; independência intelectual e liberdade acadêmica; impactos da "globalização"; financiamento e a necessidade de abordá-lo com profundidade, devido ao fato de ele estar cada vez mais comprimido em muitos países etc. (TÜNNERMANN BERNHEIM, 1995, p. 124-5).

Estudos do Banco Mundial e da UNESCO analisaram a situação do ensino superior no mundo, fizeram críticas e apresentaram as perspectivas para o futuro desse nível de ensino: La Enseñanza Superior: las lecciones derivadas de la experiencia, do Banco Mundial (BIRD, 1995); Documento de Política para a Mudança e o Desenvolvimento na Educação Superior, da UNESCO (1995) e Anais da Conferência Mundial sobre o Ensino Superior - Paris, 5 a 9 de outubro de 1998 (UNESCO; CRUB, 1999).

As principais críticas e/ou preocupações presentes nesses e em outros textos internacionais (UDUAL, 1995) relacionam-se aos seguintes aspectos das instituições de ensino superior: baixa relação aluno/professor nas universidades públicas; subutilização das instalações físicas e das habilidades dos docentes; duplicação desnecessária de programas e carreiras; altas taxas de evasão; altas taxas de repetência; excessiva soma de recursos destinada à residência estudantil, restaurantes, bolsas, subsídios etc; objetivos que não concordam com as expectativas da sociedade; formação de profissionais nem sempre requeridos pelo mercado de trabalho; desenvolvimento de ações restritas a uma só parte da população; orientação basicamente intelectualizada e superespecializada; ênfase no acadêmico e não na redução do isolamento com relação à sociedade e à vida; atuação que legitima a estratificação social existente; ação burocrática, autoritária e repressiva; passividade do estudante e ação unidirecional por parte dos professores, que centram o ensino na informação, na memorização, no conformismo e na homogeneidade, e não na crítica, na inovação e na criatividade; uso de tecnologia muito atrasada em comparação com a indústria; custos financeiros elevados e crescentes; ações escassas para desenvolver a consciência social e o espírito de solidariedade humana.

Muitos desses grandes temas apresentados pelo Grupo Assessor da UNESCO quanto Às críticas/preocupações presentes em diversos textos foram objeto de debates no interior das instituições universitárias e na sociedade brasileira, nas últimas duas décadas. Debateu-se sobre as normas que devem reger a autonomia universitária, refletiu-se sobre a estrutura organizacional das instituições e sua interação com a sociedade, especulou-se a respeito das fontes que podem financiar as suas atividades e apuraram-se custos, discutiu-se sobre a cobrança de mensalidades e sobre instrumentos de gestão, incluindo aí um processo de 
avaliação que viesse a contribuir para redefinir as funções das instituições, além de estabelecer parâmetros para aumentar a qualidade das atividades institucionais etc. A discussão de muitos desses temas, no Brasil, tem envolvido os conselhos superiores das instituições e seus dirigentes, os sindicatos, os governantes e o Parlamento. Em diversos momentos há uma grande participação da imprensa, promovendo um debate aberto à sociedade, principalmente quando o tema se relaciona a custo do aluno, cobrança de mensalidades e avaliação institucional.

Este estudo tem a finalidade de discutir o processo de autonomia e financiamento das Instituições Federais de Ensino Superior (IFES), analisar as fontes de recursos financeiros utilizados pelas Instituições, apresentar os desafios existentes neste campo de estudo e examinar possíveis ações a serem implementadas em relação a essas importantes instituições para o desenvolvimento do País. Isso se efetivará utilizando-se dos seguintes tópicos:

a) a origem do financiamento das IFES;

b) a expansão do ensino superior e os limites impostos pela desigualdade social;

c) a necessidade de expandir a educação superior;

d) o desafio do financiamento;

e) a função do Estado na educação superior e a autonomia universitária;

f) o financiamento das IFES no período 1995-2006;

g) considerações finais: desafios e ações.

\section{A Origem do Financiamento das IFES}

A origem das Instituições Federais de Ensino Superior (IFES), com a estruturação estabelecida hoje, está na Universidade do Rio de Janeiro, criada em 1920, transformada na Universidade do Brasil, em 1937, e na Universidade Federal do Rio de Janeiro (UFRJ), a partir de 1965. A Universidade do Brasil era "entendida como o 'grande projeto universitário do Governo', a partir de 1931, e implantada, em 1937, como modelo para as demais instituições de ensino superior do País." (FÁVERO, 2000, p. 12)

Houve, entretanto, na origem das IFES, uma indefinição sobre as regras de seu financiamento. Não houve a vinculação de patrimônio, nem a constituição de fundos que garantissem a continuidade de recursos financeiros para a manutenção e desenvolvimento das instituições. A obrigatoriedade do financiamento público ficou estabelecida em instrumentos legais da época, sem, entretanto, definir-se concretamente como seria o cumprimento dessa norma legal. 
A situação hoje não é muito diferente; as instituições não possuem patrimônio e fundos que gerem recursos financeiros relevantes, quando comparados com os seus orçamentos. A Lei 9394/96, a LDB, estabeleceu em relação às necessidades da universidade, em seu artigo 55, que "Caberá à União assegurar, anualmente, em seu Orçamento Geral, recursos suficientes para manutenção e desenvolvimento das instituições de educação superior por ela mantidas", mas, entretanto, não definiu concretamente a forma de se estabelecer o montante de recursos que assegurem a manutenção e desenvolvimento das instituições.

A garantia da autonomia de gestão financeira, isto é, o financiamento das atividades do meio universitário, é vital para as definições das suas políticas de ensino, pesquisa e de interação com a sociedade. A Comissão Parlamentar de Inquérito instituída em 1967 pelo Congresso Nacional para discutir a forma de organização jurídica das universidades públicas colheu depoimento de Zeferino Vaz sobre a opção entre as formas de autarquias ou fundações. O então Reitor da Unicamp posicionou-se dizendo que a questão mais séria não era a forma de organização jurídica, mas sim, o "quantum que o governo põe à disposição" da universidade:

o problema não é ser autarquia ou fundação, mas é o quantum que o Governo põe à disposição [da universidade]. A função da universidade é produzir cultura e não dinheiro. $\mathrm{O}$ dinheiro deve ser suprido pelo Governo e hoje é suprido pelo Governo mesmo nas mais ricas universidades do mundo. As universidades de Harvard, de Columbia, da Califórnia, que são consideradas universidades riquíssimas e que têm patrimônio imenso, acumulado por séculos, hoje vivem sobretudo das subvenções do Governo Federal dos Estados Unidos e crescem cada vez mais. Portanto, é indiferente a estrutura de fundação ou autarquia. Não adianta ser fundação, se da dotação orçamentária de NCr\$ 15.000.000,00 o Governo entende de dar NCr\$10.000.000,00. (CPI apud SGUISSARDI, 1993, p. 62; grifos nossos)

Com a determinação constitucional de 1988 que, em seu artigo 207, estabeleceu a autonomia universitária, esperava-se que houvesse, efetivamente, a discussão de vários problemas das instituições de ensino superior públicas, tais como a falta de autonomia para as mais simples ações administrativas e orçamentárias; a crônica escassez de recursos para o financiamento de suas ações e expansão do sistema; e a inexistência de ações colaborativas entre elas. Entretanto, a partir de 1990, os presidentes eleitos iniciaram, no Brasil, a implantação das políticas presentes em orientações internacionais que foram elaboradas após a crise do Estado de Bem-Estar Social europeu. Na economia, 
foram implantadas reformas que privatizaram empresas estatais, congelaram salários, protegeram o sistema financeiro e abriram o mercado nacional para produtos estrangeiros. No ensino superior, o que se viu foi, no contexto do "quase-mercado" educacional, uma pregação em favor do eficientismo, da competição entre as instituições, da implantação de um gerenciamento administrativo/acadêmico que segue padrões de empresas privadas, e da procura por fontes alternativas de financiamento que complementassem as do fundo público.

A UNESCO, em sua Conferência Mundial sobre o Ensino Superior, realizada em Paris, de 5 a 9 de outubro de 1998, elaborou os documentos "Declaração Mundial sobre Educação Superior no Século XXI" (UNESCO; CRUB, 1999) e "Marco referencial de ação prioritária para a mudança e o desenvolvimento do ensino superior" (IDEM, 1999), em que se faz uma análise dos compromissos e funções da educação superior. Sobre o aporte de recursos financeiros para a manutenção e o desenvolvimento do ensino superior, a Conferência concluiu que "o financiamento da educação superior requer recursos públicos e privados":

O Estado mantém seu papel essencial nesse financiamento. O financiamento público da educação superior reflete o apoio que a sociedade presta a esta educação e deve, portanto, continuar sendo reforçado, a fim de garantir o desenvolvimento da educação superior, aumentar a sua eficácia e manter sua qualidade e relevância. Não obstante, o apoio público à educação superior e à pesquisa permanece essencial, sobretudo como forma de assegurar um equilíbrio na realização de missões educativas e sociais. (UNESCO; CRUB, 1999, p. 29)

Deve-se lembrar que a abrangência nacional das IFES constitui-se em importante fator de redistribuição da riqueza nacional, por permitir a formação de profissionais altamente qualificados em todo o território nacional, além de desenvolver atividades de pós-graduação, pesquisa e de extensão locais, o que contribui para a redução da desigualdade tecnológica entre as regiões do País e a dependência dos Estados que se encontram num estágio de formação de pesquisadores, em relação àqueles que já conseguiram consolidar as atividades que possibilitam a geração e absorção de conhecimento. $\mathrm{O}$ fato de as instituições públicas de ensino superior brasileiras serem responsáveis por mais de $90 \%$ da produção científica do País mostra a sua importância no conjunto de ações a serem realizadas visando o desenvolvimento econômico e social brasileiro. A tabela 01 mostra a distribuição dos programas de pós-graduação nos Estados brasileiros e ilustra a importância das instituições federais de educação superior para minimizar as assimetrias regionais do país. 
Tabela 01 - Número de programas de pós-graduação das IES em cada Estado

\begin{tabular}{|c|c|c|c|c|c|}
\hline Estado & Federal & Estadual & Municipal & Particular & Com/Conf/Filan \\
\hline Rondônia & 2 & - & - & - & - \\
\hline Acre & 1 & - & - & - & - \\
\hline Amazonas & 21 & 1 & - & - & - \\
\hline Roraima & - & - & - & - & - \\
\hline Pará & 29 & - & - & 2 & - \\
\hline Amapá & - & - & - & - & - \\
\hline Tocantins & 1 & - & - & - & - \\
\hline Maranhão & 8 & 1 & - & - & - \\
\hline Piauí & 6 & - & - & - & - \\
\hline Ceará & 40 & 7 & - & 5 & - \\
\hline Rio Gr. do Norte & 31 & - & - & - & - \\
\hline Paraíba & 39 & - & - & - & - \\
\hline Pernambuco & 64 & 2 & - & - & 3 \\
\hline Alagoas & 10 & - & - & - & - \\
\hline Sergipe & 7 & - & - & - & - \\
\hline Bahia & 37 & 9 & - & 5 & - \\
\hline Minas Gerais & 144 & 2 & - & 7 & 12 \\
\hline Espírito Santo & 17 & - & - & 2 & - \\
\hline Rio de Janeiro & 164 & 39 & - & 20 & 30 \\
\hline São Paulo & 70 & 391 & 3 & 43 & 60 \\
\hline Paraná & 49 & 54 & - & 4 & 12 \\
\hline Santa Catarina & 46 & 6 & 4 & - & 7 \\
\hline Rio Gr. do Sul & 112 & - & - & 1 & 57 \\
\hline Mato G. do Sul & 15 & - & - & 2 & 3 \\
\hline Mato Grosso & 9 & - & - & - & - \\
\hline Goiás & 22 & - & - & - & 4 \\
\hline Distrito Federal & 48 & - & - & 1 & 7 \\
\hline TOTAL & 992 & 512 & 7 & 92 & 195 \\
\hline \multicolumn{5}{|c|}{ Fonte: CAPES, Avaliação Trienal 2004, DAV/CAA } & \\
\hline
\end{tabular}

O número de alunos de graduação de todas as IFES passou de $366.313 \mathrm{em}$ 1995 para 553.320 em 2005, um aumento de $51 \%$, expansão que não foi acompanhada de uma ação que ampliasse os recursos financeiros das instituições, visando a solução de muitos de seus problemas.

O que levou as Instituições a aumentarem o número de alunos mesmo sem terem expansão dos recursos financeiros? Será que pressionadas pelas crises de hegemonia, de legitimidade e institucional (SOUSA SANTOS, 1999, p. 190) e sob campanha pública difamatória? Outros fatores de pressão poderiam ainda colaborar para explicar a série crescente no número de estudantes de graduação: 
a) a implantação de fórmulas dependentes da produtividade individual que objetivam justificar a alocação dos recursos financeiros para as instituições, com forte dependência do número de alunos das IFES;

b) a pressão existente pelo aumento na quantidade de alunos devido ao fato do baixo percentual brasileiro da população de jovens com idade entre 18 e 24 anos, matriculados em ensino superior;

c) a implantação da Gratificação de Estímulo à Docência (GED) que incentivou a elevação da carga horária dos professores; um valor financeiro só é incorporado ao salário se houver, em contrapartida, um determinado número de hora, do docente, a mais em salas de aula.

Não se pode, entretanto, falar de um conjunto de instituições de ensino superior públicas de um país, sem antes falar do que se espera desse conjunto de instituições. Em geral, o mais comum, e o que ocorre em países que conseguem elevados índices de desenvolvimento material e tecnológico, é esperar que essas instituições possam contribuir para o país enfrentar com êxito os desafios presentes na sociedade, no que diz respeito tanto ao desenvolvimento social, econômico e cultural, como à contribuição para assegurar a competitividade técnica da economia nacional, no contexto internacional (BERCHEM, 1990, p. 9; CONCEIÇÃO et al., 1998, p. iii).

\section{A Expansão do Ensino Superior e os Limites à Expansão Privada Impostos pela Desigualdade Social}

Dados do PNAD/IBGE de 2006 informam que existiam no Brasil 24.285.000 jovens com idade entre 18 e 24 anos. Deste total de jovens a pesquisa do IBGE mostrou que $673.000(2,8 \%)$ são analfabetos e 7.704 .000 (31,7\%) estão estudando. Um percentual dos jovens nessa faixa etária já se graduaram e exercem atividades diversas no mercado de trabalho. O perfil escolar desse contingente de estudantes pode ser examinado na tabela 02 .

Tabela 02 - Perfil escolar dos estudantes com idade entre 18 e 24 anos

\begin{tabular}{lrrr}
\hline Total & $\begin{array}{c}\text { Ensino } \\
\text { Fundamental }\end{array}$ & $\begin{array}{c}\text { Ensino } \\
\text { Médio* }^{*}\end{array}$ & $\begin{array}{c}\text { Ensino } \\
\text { Superior }\end{array}$ \\
\hline 7.704 .000 & 1.249 .000 & 3.364 .000 & 3.091 .000 \\
\hline
\end{tabular}

Fonte: PNAD/IBGE - 2006

* Inclusive os estudantes de pré-vestibulares.

** Inclusive os estudantes de mestrado e doutorado 
Desses 7.704.000 jovens, $16,2 \%$ ainda estão matriculados no ensino fundamental e $43,7 \%$ estão matriculados no ensino médio. Portanto, do total de 24.285.000 jovens com idade entre 18 e 24 anos apenas 3.091 .000 (12,7\%) estão matriculados na educação superior. Deve-se lembrar que uma das metas do PNE a ser atingida em 2011 é que 30\% desses jovens estejam matriculados na educação superior.

A pesquisa do IBGE mostra ainda que estavam matriculados na educação superior brasileira, em 2006, um total de 5.874.000 alunos, sendo que 1.439.000 (24,5\%) estão matriculados em instituições públicas e 4.434 .000 (75,5\%) estão matriculados em instituições privadas.

Adesigualdade na distribuição de renda do Brasil mostra números alarmantes (BRASIL.PNAD/IBGE, 2006): 20.157 .000 brasileiros residem em domicílios em que o rendimento mensal domiciliar é de até um salário mínimo; 39.792.000 moram em domicílio cuja renda é de um a dois salários mínimos. Um percentual elevado da população, 70,3\%, mora em domicílio cuja renda domiciliar mensal é de até cinco salários mínimos. Apenas 3,0\% das pessoas vivem em domicílios em que a renda domiciliar é maior do que 20 salários mínimos.

A tabela 03 mostra esse perfil de desigualdade, onde vive um total de 186.362.000 pessoas (IDEM, 2006).

Tabela 03 - Moradores em domicílios particulares, por classe de rendimento mensal domiciliar

\begin{tabular}{lrr}
\hline $\begin{array}{c}\text { CLASSE DE RENDIMENTO MENSAL } \\
\text { DOMICILIAR DE TODAS AS FONTES (1) }\end{array}$ & MORADORES (2) & $\%$ \\
\cline { 1 - 2 } \multicolumn{1}{c}{ (Salário Mínimo = S.M.) } & & \\
\hline Até 1 S.M. & 20.157 .000 & 10,8 \\
\hline Mais de 1 a 2 S.M. & 39.792 .000 & 21,4 \\
\hline Mais de 2 a 3 S.M. & 33.090 .000 & 17,8 \\
\hline Mais de 3 a 5 S.M. & 37.886 .000 & 20,3 \\
\hline Mais de 5 a 10 S.M. & 31.884 .000 & 17,1 \\
\hline Mais de 10 a 20 S.M. & 12.692 .000 & 6,8 \\
\hline Mais de 20 S.M. & 5.644 .000 & 3,0 \\
\hline Sem rendimentos (3) & 1.197 .000 & 0,6 \\
\hline Sem declaração & 4.020 .000 & 2,2 \\
\hline TOTAL & 186.362 .000 & 100,0 \\
\hline
\end{tabular}

Fonte: IBGE, 2006

(1) Exclusive os rendimentos dos moradores cuja condição no domicílio era pensionista, empregado doméstico ou parente do empregado doméstico.

(2) Inclusive os domicílios cujos moradores receberam somente benefícios. 
Os rendimentos médios mensais desses moradores estão na tabela 04. Notase, portanto, que as famílias que ganham até 5 salários mínimos não conseguiriam manter uma pessoa estudando em instituições particulares, pagando mensalidades.

Tabela 04 - Rendimento médio mensal das famílias residentes em domicílios particulares $(\mathrm{R} \$)$

\begin{tabular}{lc}
\hline $\begin{array}{l}\text { CLASSES DE RENDIMENTO MENSAL DOMICILIAR } \\
\text { EM SALÁRIO MÍNIMO-S.M. (1) }\end{array}$ & VALOR EM R\$ (1)(2) \\
\hline Até 1 S.M. & 257 \\
\hline Mais de 1 a 2 S.M. & 544 \\
\hline Mais de 2 a 3 S.M. & 882 \\
\hline Mais de 3 a 5 S.M. & 1.359 \\
\hline Mais de 5 a 10 S.M. & 2.431 \\
\hline Mais de 10 a 20 S.M. & 4.856 \\
\hline Mais de 20 S.M. & 12.199 \\
\hline
\end{tabular}

Fonte: IBGE, 2006

(1) Exclusive os rendimentos dos moradores cuja condição no domicílio era pensionista, empregado doméstico ou parente do empregado doméstico.

Iremos estimar quantas famílias poderiam pagar mensalidades para uma pessoa estudando em uma instituição privada, considerando a elevada inadimplência (em torno de $30 \%$ ) e o grande percentual de vagas do vestibular não preenchidas no setor privado (mais da metade). Para isso, consideraremos que somente aquelas famílias com renda a partir de 5 salários mínimos poderiam dirigir percentuais de seus rendimentos para efetivarem o pagamento de mensalidades para seus filhos e ainda, daqueles que ganham de 5 a 10 salários mínimos somente a metade de salários mais elevados poderiam fazê-lo, teríamos um total de 34.278.000 pessoas nessas condições. Supondo que deste total 13\% são jovens com idade de 18 a 24 anos (mesmo percentual dessa faixa etária na população brasileira), teríamos 4.456 .140 jovens que poderiam pagar mensalidades. Como já estão matriculados nas instituições privadas 4.434 .000 estudantes e se supusermos que uma certa quantidade de jovens que poderiam pagar estão matriculados hoje nas instituições públicas, pode-se concluir que o limite de expansão do setor privado já está alcançado, pela impossibilidade das famílias pagarem mensalidades. 


\section{A Necessidade de Expandir a Educação Superior}

A grande ampliação das instituições privadas colabora para oferecer à população uma maior oportunidade de acesso ao ensino universitário, por outro lado, deixam como resultados outros graves problemas a serem resolvidos:

a) o grande percentual de estudantes de graduação matriculados em instituições privadas;

b) a enorme quantidade de instituições utilitaristas atuando nesse nível de ensino.

Algumas comparações internacionais mostram a realidade relacionada ao primeiro problema. No Brasil, em 2006, o percentual de jovens entre 18 e 24 anos estudando na educação superior era de $12,7 \%$. No Chile, esse percentual era de 20,6\%, na Venezuela, 26\%, e na Bolívia, 20,6\% (PNE, 2000). A situação da Argentina, com um percentual de $40 \%$, é especial e precisa ser ressaltada: "configura um caso à parte, uma vez que adotou o ingresso irrestrito, o que se reflete em altos índices de repetência e evasão nos primeiros anos." (PNE, 2000).

Dessa informação pode-se concluir então que: a) se quiséssemos alcançar a meta - prevista no PNE - de 30\% dos jovens com idade entre 18 e 24 anos matriculados na educação superior, precisaríamos ter matriculados nesse nível educacional, em 2006, no mínimo 7.285.500 estudantes; e b) e, simultaneamente, fazer crescer o percentual de estudantes matriculados em instituições públicas que provoque, por exemplo, uma elevação do percentual de estudantes nas públicas, o que exigiria uma substancial elevação dos recursos do fundo público aplicados nesse nível de ensino. Este é um objetivo que, para ser alcançado, deverá contar com decisivas opções de política pública e com a existência de longos períodos de desenvolvimento do País - crescimento contínuo do PIB e de sua renda per capita.

$\mathrm{O}$ conjunto de dados explicitados anteriormente parece levar-nos à conclusão que se atingiria a meta de $30 \%$ dos jovens, com idade entre 18 e 24 anos, matriculados no ensino superior, apenas ampliando o número de vagas nas escolas privadas, uma vez que o Presidente Fernando Henrique Cardoso vetou a meta prevista no Plano Nacional de Educação (PNE), que planejava a expansão do ensino superior público: "Ampliar a oferta de ensino público de modo a assegurar uma proporção nunca inferior a $40 \%$ do total de vagas, prevendo inclusive a parceria da União com os Estados na criação de novos 
estabelecimentos de educação superior." Atingir essas metas significaria termos 7.285.500 estudantes nesse nível de ensino e, destes, $40 \%$, ou seja, um total de 2.914.200 matriculados em instituições públicas, o que significaria quase duplicar a quantidade atual de alunos que é de 1.439.000 (BRASIL.PNAD/ IBGE, 2006) e $60 \%$, ou seja, um total de 4.371 .300 alunos matriculados nas instituições particulares.

A efetiva ampliação da educação superior pública justifica-se pela garantia do direito à educação e ainda pela limitação ao crescimento do número de alunos no setor privado, como já mostramos, imposta pela renda per capita brasileira e pela enorme desigualdade social do país - $10 \%$ mais ricos possuem $50 \%$ da riqueza e $50 \%$ mais pobres possuem $10 \%$ da riqueza (NERI, 2000, p. 22).

As análises realizadas reforçam ainda mais a necessidade da existência de ações governamentais para que ocorra uma vigorosa expansão do ensino superior público. O restabelecimento das metas de expansão previstas no PNE movimentaria os governantes, os parlamentares e mobilizaria as instituições de ensino superior e a sociedade para que elas fossem alcançadas.

\section{O Desafio do Financiamento}

Um desafio existente no financiamento da educação superior pública federal é responder à seguinte pergunta: quais seriam os "recursos suficientes para manutenção e desenvolvimento" das instituições mantidas pela União? Esta pergunta é feita em vista do que está contido no artigo 55 da Lei de Diretrizes e Bases da Educação Nacional (LDB), que afirma: "Caberá à União assegurar, anualmente, em seu Orçamento Geral, recursos suficientes para manutenção e desenvolvimento das instituições de educação superior por ela mantidas". (Grifos nossos).

Encontrar o mecanismo de financiamento que responderia satisfatoriamente a esse questionamento é uma das mais complexas tarefas a ser enfrentada na implantação da autonomia prevista no artigo 207 da Constituição Federal.

Diversos autores classificam em quatro os mecanismos que os Estados utilizam para financiar o ensino superior (CONCEIÇÃO et al, 1998; VELLOSO, 2000; JONGBLOES; MAASSEN, 1999)

a) financiamento Incremental ou Inercial;

b) financiamento por Fórmulas;

c) financiamento Contratual;

d) financiamento por subsídios às mensalidades dos estudantes. 
No financiamento incremental ou inercial, os recursos financeiros a serem estabelecidos num determinado ano baseiam-se nos recursos do ano anterior. A definição do novo valor que é estabelecido unilateralmente pelo Governo, ou negociado entre o Governo e a instituição ou, simplesmente, especificado um percentual de incremento ano a ano.

No financiamento contratual se estabelece, entre a instituição e o Estado, materializado num contrato, um acordo em que a IES se "compromete a concretizar um determinado programa ou a atingir determinados objetivos, recebendo para isso uma contrapartida do Estado.” (CONCEIÇÃO et al., 1998, p. 86).

No financiamento por subsídios às mensalidades dos estudantes, utilizam-se os cheques educacionais. Esse método consiste no seguinte:

a parcela de receitas que o Estado cobra em impostos e destina à educação é dividido em cheques, estes são repassados aos estudantes para freqüentarem as universidades que entenderem. Desta forma as universidades que têm que competir entre si, sujeitando-se exclusivamente às regras de mercado, dependentes apenas da escolha dos estudantes. Embora admitida freqüentemente como metodologia de financiamento, a dificuldade em prever as conseqüências da alteração da relação aluno/universidade resultantes da implementação do conceito tem limitado a sua concretização. (IDEM, 1998, p. 184, grifos nossos)

O financiamento por fórmulas se dá pelo estabelecimento de variáveis/indicadores institucionais que participam de uma expressão lógica que indica no final qual percentual ou valor deve se direcionar para cada instituição que participa da distribuição. Velloso (2000, p. 49) exemplifica essa:

podem envolver a combinação de um largo espectro de variáveis, relativas à manutenção da instituição, como o número de docentes e de alunos em cada instituição, até indicadores tidos como de desempenho, como a relação entre matrícula nova e o quantitativo de diplomados, passando por índices tidos como de eficiência, a exemplo das relações médias aluno/docente, por universidade ou área do conhecimento.

A programação financeira das IFES se dá por uma sistemática mista que mistura a do Financiamento Incremental ou Inercial e a do Financiamento por Fórmulas. Os recursos financeiros a serem estabelecidos num determinado ano baseiam-se nos recursos do ano anterior; o volume de recursos é estabelecido pelo Governo Federal e aprovado pelo Congresso Nacional, sem nenhuma 
consulta sobre as reais necessidades das instituições. O MEC determina, separadamente, o volume de recursos para o pagamento de pessoal e o volume para manutenção e investimentos. No caso da distribuição dos recursos de manutenção e investimentos entre as IFES, elas já vêm, há alguns anos, exercitando um modelo de Financiamento por Fórmulas, implantado em um acordo entre o MEC e a Associação Nacional de Dirigentes das IFES (ANDIFES). Esse modelo considera parâmetros que procuram medir necessidades e desempenho (ANDIFES, 1994). Apesar de todas as deficiências presentes inicialmente em tal modelo e na sua reformulação ocorrida em 1999 exigindo, portanto, revisão e aprimoramentos, a sua implantação procurou deixar claras as "regras do jogo" para se obter recursos de manutenção e investimentos, abandonando-se regras desconhecidas que poderiam possibilitar negociações clientelistas.

\section{A Função do Estado na Educação Superior e a Autonomia Universitária}

Com relação ao papel do Estado, na educação superior, a orientação predominante a partir de 1989 foi sempre a de que este deveria ser reformulado, transformando-se em normatizador, fiscalizador e avaliador, ao invés de executor. As instituições de ensino superior deveriam possuir maior autonomia, e esta estaria sujeita às ações de Governo: credenciamento, recredenciamento, avaliação, fiscalização etc.

Em outubro de 1991, o governo Collor encaminhou ao Congresso Nacional uma proposta de emenda constitucional $\left(\mathrm{PEC}^{\circ}\right.$ 56/91) que procurava alterar vários artigos da Constituição, incluindo-se o artigo 207, que estabeleceu a autonomia universitária. São alguns pontos desta PEC: as universidades passariam a gozar, também, de autonomia para gerir seus recursos humanos; aqueles que trabalham nas universidades teriam regime jurídico especial, ficando, portanto, excluídos do Regime Jurídico Único (RJU), Lei no 8.112, de 1990; as universidades seriam entidades de natureza jurídica própria; as universidades receberiam percentuais fixos dos recursos destinados constitucionalmente à educação e nos seus orçamentos não poderiam ser destinados mais do que $80 \%$ dos recursos ao pagamento de pessoal.

O MEC explicitava suas propostas na imprensa, em reuniões com reitores e em discussões com uma Comissão da ANDIFES especialmente constituída para debater esta questão:

a) dos $18 \%$ dos recursos alocados para a educação no orçamento da União, $50 \%$ seriam dedicados ao ensino superior; 
b) as universidades gerenciariam um orçamento global, com liberdade de transferir recursos de pessoal para custeio e capital e vice-versa;

c) para efetivar a distribuição de recursos entre as IFES seria desenvolvido um modelo que consideraria número de formandos, número de mestres e doutores, conceito CAPES para a pós-graduação, área física etc.;

d) as dívidas trabalhistas deveriam ter tratamento especial;

e) a implantação se daria a partir de 1993.

Em março de 1992, no documento "Algumas observações sobre a autonomia universitária", documento para discussão na ANDIFES, a comissão criada para negociar com o MEC apresentava sua desconfiança em relação às propostas governamentais e faziam as seguintes análises (ANDIFES, 1992, p. 4):

Existe considerável desconfiança no seio da comunidade universitária sobre as reais vantagens de se efetivar, de imediato, a autonomia das IFES. A desconfiança é plenamente justificada, considerando-se o nível de incerteza que tem caracterizado a vida financeira das IFES nos últimos anos. Orçamentos não são cumpridos, recursos são contingenciados, repasses de verbas são absolutamente irregulares e a própria execução orçamentária tem sofrido os prejuízos inevitáveis decorrentes dos grandes atrasos na aprovação e sanção do orçamento geral da União. (grifos nossos).

Com o impeachment do Presidente Collor, em 1992, toda essa discussão foi interrompida.

Nessa época, elaborava-se a nova LDB em que também se abordava o tema da autonomia universitária. Entretanto, nenhuma das propostas contemplava objetivamente os assuntos relacionados a orçamento, finanças e pessoal. Ações políticas se realizaram para tentar a viabilização de uma Lei Complementar que pudesse regulamentar pontos importantes para o real exercício da autonomia, nos termos da Constituição Brasileira. Participaram do processo o Deputado Ubiratan Aguiar, através do Projeto de Lei Complementar nº 119, de 1992, e o Deputado Florestan Fernandes, como relator.

Apresentavam-se os seguintes pontos na discussão (CRUB, 1992):

a) a dotação global para as IFES deveria ser definida a partir do percentual da receita de impostos vinculados à manutenção e ao desenvolvimento do ensino; 
b) a dotação global para cada instituição deveria assegurar recursos para pessoal e outros custeios e capital, de tal modo que estes equivalessem, no mínimo, a 25\% daqueles;

c) uma parcela de $10 \%$ dos recursos totais de OCC seria alocada ao MEC, com a finalidade de fomentar o desenvolvimento institucional;

d) a repartição dos recursos entre as IFES utilizaria critérios que considerariam dimensão e desempenho;

e) haveria isonomia de carreiras e pisos salariais, com a possibilidade de diferenciação de remuneração, financiada com recursos financeiros obtidos pela instituição, além daqueles do Fundo Público Federal;

f) seriam fixados quadros de pessoal, em articulação com o MEC, de acordo com critérios de áreas, habilitações e dimensão; seriam estabelecidas relações obrigatórias entre dimensão do corpo técnico-administrativo e corpo docente (no máximo igual a 1,5) e de despesas com ambos os corpos (no máximo igual a 1);

g) as contratações adicionais temporárias ou atribuições adicionais de regime de trabalho deveriam ser financiadas por outras fontes distintas da dotação global etc.

A indefinição de percentuais de recursos para a manutenção e desenvolvimento das instituições; a utilização de critérios empresariais para a alocação de recursos; a objetividade matemática na determinação do quadro técnicoadministrativo e docente; e a sinalização da ida ao mercado à procura de recursos complementares, entre outras, fizeram com que essas discussões não prosperassem. Há que se lembrar ainda que o Presidente Itamar Franco havia assumido a Presidência da República para um mandato de dois anos, tempo insuficiente para se implantarem mudanças substanciais no que se refere às normas pertinentes ao quadro de pessoal.

Com a posse de novo governo, no ano de 1995, tendo à frente o ex-Senador Fernando Henrique Cardoso, foi apresentado o documento "A política para as Instituições Federais de Ensino Superior" (BRASIL.MEC, 1995), contendo os seguintes pontos "essenciais da política a ser implantada":

1) Promover a plena autonomia de gestão administrativa e financeira das universidades federais, preservando sua condição atual de entidades de direito público.

2) A autonomia de gestão administrativa deverá incluir o poder de cada universidade decidir autonomamente sobre sua política de pessoal, in- 
cluindo contratações e remunerações, observando parâmetros mínimos comuns de carreira docente e de pessoal técnico-administrativo.

3) O governo federal definirá a cada ano um orçamento global para cada universidade, que será repassado em duodécimos e administrado autonomamente por cada uma delas.

4) O Governo Federal manterá pelo menos nos níveis reais atuais o gasto anual com as universidades e demais instituições de ensino superior.

5) O Ministério da Educação, ouvidos os Reitores das Universidades Federais, fixará os critérios para a distribuição dos recursos entre as instituições, levando em consideração a avaliação de seu desempenho e buscando estimular o aumento da eficiência na aplicação dos recursos públicos e a ampliação do atendimento à população.

6) As universidades serão estimuladas a buscar fontes adicionais de recursos junto a outras esferas do poder público e à iniciativa privada para ampliar $o$ atendimento a outras demandas sociais que não o ensino.

7) Nas instituições públicas federais os cursos de graduação, mestrado e doutorado serão gratuitos.

8) Os hospitais de ensino serão subordinados academicamente às universidades, mas gozarão de autonomia administrativa com gestão profissional.

As instituições deveriam decidir sobre pessoal - contratações e remunerações; os orçamentos seriam globais, ou seja, os recursos poderiam ser transferidos de pessoal para manutenção e investimentos e vice-versa; não haveria aumento dos recursos financeiros do FPF para as IFES; os recursos seriam distribuídos utilizando-se critérios que buscassem a eficiência e ampliação de atividades; as instituições deveriam procurar fontes adicionais ao FPF; os cursos de especialização e extensão deixariam de ser gratuitos e os hospitais de ensino seriam, administrativamente, separados das instituições.

No início do governo Fernando Henrique Cardoso, com o firme propósito de transformar as IFES em Organizações Sociais, sob a configuração apresentada até aqui, o MARE deu conhecimento à comunidade universitária de documento contendo 12 "etapas para viabilização da aplicação da Lei de Organizações Sociais na recriação de Universidade Pública a ser administrada por Contrato de Gestão".

Ocorreram muitos questionamentos a essa reestruturação das IFES e a idéia foi abandonada pelo Governo Federal. 
No documento "Propostas de Reforma Constitucional", apresentado em outubro de 1995, o MEC propõe uma alteração para o artigo 207 da Constituição do Brasil, que acrescenta a expressão "na forma da lei" ao texto constitucional. Grande reação a essa desconstitucionalização da autonomia universitária fez com que a proposta não obtivesse êxito.

A partir da rejeição à proposta do Governo, instala-se uma grande discussão nas diversas instâncias relacionadas à questão: MEC, ANDIFES, CRUB, ANUP, ABRUEM, FASUBRA e UNE. O primeiro embate se dá em torno da auto-aplicabilidade do artigo 207, e divergências de interpretação se apresentam em toda a extensão da discussão.

O caminho seguido pela ANDIFES foi o proposto por José Alfredo de Oliveira Baracho, em "Autonomia Universitária: questões constitucionais e legais à autoaplicabilidade do artigo 207”, parecer fornecido à ANDIFES sobre aspectos da autonomia universitária:

Diante deste quadro, embora sendo desnecessária a regulamentação, é legítima a idéia de uma Lei Orgânica das Universidades, que venha melhor definir a autonomia, evitando que uma lei com conteúdo indesejável seja votada pelo Congresso diante da ausência de participação das Universidades neste processo, sendo que para sua elaboração não é necessária a alteração do texto constitucional. (BARACHO, 1996)

Trabalhando nessa perspectiva, em 1996, a ANDIFES apresentou ao MEC a proposta de um anteprojeto de Lei: "Lei Orgânica das Universidades", aprovado em João Pessoa - PB, em 01 de outubro de 1996, contendo regulamentação sobre (ANDIFES, 1996):

a) a natureza jurídica das Universidades;

b) em que consiste a autonomia didático-científica, a autonomia administrativa e a autonomia de gestão financeira e patrimonial;

c) a existência de um Sistema Federal de Ensino Superior;

d) o regime jurídico dos professores e técnico-administrativos;

e) as regras para o financiamento etc.

Com relação ao item sobre o financiamento das IFES, a ANDIFES se conduziu com cautela. Nas estaduais paulistas, a implantação da autonomia se deu com um aumento dos percentuais de recursos que se destinavam, historicamente, às Universidades. Os valores totais, até 1986, ficavam em torno de 5\% do ICMS 
paulista; o valor de 1987 , foi de $7,73 \%$ e o valor de 1989 , quando da implantação da autonomia, foi de 8,4\%. Em 1992, ele passou para 9,0\% e hoje ele é de $9,57 \%$, sendo que, em 1998, discutia-se a elevação desse percentual para $11,0 \%$. Esses diversos aumentos em apenas oito anos aconteceram depois de longas discussões que envolveram os dirigentes, a comunidade universitária, as entidades sindicais, os poderes executivo e legislativo, e se justificaram tanto pela necessidade da melhoria das condições salariais e de trabalho quanto pela expansão das atividades de ensino, pesquisa e extensão.

Um fato gravíssimo na implantação da autonomia das universidades paulistas foi a inclusão do pagamento dos aposentados nos recursos que se dirigiam a cada universidade. Na Unicamp, por exemplo, em 1989, 66\% do orçamento se destinava ao pagamento de salários - incluindo-se os dos aposentados - e, em 1998, esse percentual chegou a 95\%. É claro que não só o pagamento de aposentados é responsável por essa situação; o aumento da qualificação dos professores, que praticamente dobrou o número de docentes com o título de doutor, fez também aumentar as despesas com a folha de pagamento de pessoal.

Admitindo-se que o orçamento das IFES seja global, a experiência paulista nos indica que as questões básicas a serem debatidas com relação ao financiamento são: 1) como definir o montante de recursos a ser distribuído? 2) como tratar os fundos, como o FEF que faz uma desvinculação orçamentária dos recursos para a educação? 3) como garantir a suficiência dos recursos ao longo do tempo? 4) quais os critérios a serem utilizados para distribuir entre as IFES o montante de recursos? e (5) como efetuar o pagamentos dos aposentados?

Nova postura do MEC, entretanto, mudou o rumo das discussões; de uma discussão sobre a autonomia das universidades brasileiras, como estava em debate, passou-se a regulamentar apenas a autonomia das IFES, ou seja, somente das instituições públicas federais. A partir dessa decisão, o ponto central da definição do financiamento das IFES passa a se situar no estabelecimento de um Fundo de Manutenção e Desenvolvimento do Ensino Superior como um percentual dos recursos vinculados à educação, e sob a gerência da União. Essa discussão se deu através do Projeto de Emenda Constitucional n ${ }^{\circ} 370$, apresentada pelo Governo ao Congresso Nacional.

O próprio nome do Fundo gera polêmica, pois a manutenção e desenvolvimento do ensino superior deixa-o aberto ao financiamento de crédito educativo, repasse para as instituições estaduais, municipais etc. Define-se que ele seria constituído de $75 \%$ dos recursos vinculados à educação e que fazem parte do FPF. Seria suficiente? Permitiria a expansão do sistema? Como incluir os recursos desvinculados pelos Fundos, como o FEF? 
Em todas as propostas do MEC estava presente a retirada do pagamento de inativos e pensionistas do cálculo do montante a ser destinado ao financiamento das instituições.

Entretanto, um ponto decisivo para a interrupção da discussão sobre a subvinculação de recursos para um fundo que financiaria as IFES ocorreu quando o Governo apresentou a proposta de que o fundo composto de $75 \%$ dos recursos vinculados constitucionalmente à União deixaria de existir após 10 (dez) anos. Imediatamente, os apoios à proposta de constituição do fundo se esvaíram.

Com a posse do Governo Lula houve uma grande discussão do que se chamou de Reforma Universitária, mas nenhuma reformulação legal efetiva ocorreu e o projeto encontra-se no Congresso Nacional sem trazer nenhuma proposta de mudança essencial para as IFES uma vez que ela se resume a subvincular recursos e, como antes, por 10 anos.

Portanto, no que se relaciona ao cumprimento do artigo 207 da Constituição Federal, que estabelece a autonomia universitária, não houve nenhum avanço de 1989 a 2006. Primeiro, a comunidade universitária, incluindo os seus dirigentes, é permanentemente temerosa e crítica em relação às propostas emanadas do Poder Executivo e, depois, o próprio Governo parece não querer abrir mão do poder que ele detém sobre as instituições, quando gerencia os seus orçamentos.

Dessa forma, a regulamentação da autonomia financeira das IFES não se concretizou no período após a Constituição de 1988, e elas continuam a depender integralmente das definições orçamentárias estabelecidas pelo Poder Executivo e aprovadas pelo Congresso Nacional.

\section{O Financiamento das IFES no Período 1995-2006}

Os recursos do fundo público federal que financiam as atividades das IFES são divididos em recursos diretamente arrecadados, chamados de recursos próprios; recursos provenientes de convênios/contratos com organismos públicos e/ou privados e recursos oriundos das outras fontes, como impostos, taxas, contribuições etc., que são chamados de recursos do Tesouro Nacional. Os recursos próprios são provenientes de prestação de serviços pelas diversas unidades da instituição, prestação de serviços ao Sistema Único de Saúde (SUS) pelos Hospitais Universitários (HU's), taxas internas, aluguéis, doações, receitas resultantes de aplicações no mercado financeiro etc.

A separação entre recursos próprios e recursos do Tesouro Nacional, tem o objetivo de deixar bem claro quais são os recursos que a própria instituição 
conseguiu diretamente pelas suas ações na sociedade - recursos próprios e convênios/contratos - e quais são aqueles que a instituição recebeu diretamente da arrecadação de tributos, chamados recursos do tesouro.

Serão analisados, primeiro, os recursos das IFES, excetuando-se os recursos próprios e, depois, os recursos próprios arrecadados e que foram executados via Orçamento Geral da União. Existe uma parcela de recursos das IFES que é intermediada por fundações de direito privado que apóiam as atividades das instituições. Esses recursos não fluem através da execução orçamentária institucional e, além de pagarem a execução de convênios/contratos, assessorias e consultorias, permitem uma complementação salarial aos professores e servidores técnico-administrativos que participam da execução dos projetos.

Excluindo-se, portanto, os recursos próprios, os recursos gastos com as IFES nos grandes blocos de despesa: Pessoal e Encargos Sociais, Encargos da Dívida, Outras Despesas Correntes, Investimentos, Inversões Financeiras e Amortização da Dívida estão na tabela 05. O gráfico 01 mostra o total de recursos das IFES no período 1995-2006.

Tabela 05 - Recursos das IFES, grandes blocos de despesa (1995-2006), excluindo-se os recursos próprios

Valores em R\$ milhões, a preços de janeiro de 2007 (IGP-DI/FGV)

\begin{tabular}{cccccccc}
\hline Ano & $\begin{array}{c}\text { Pessoal e } \\
\text { Encargos } \\
\text { Sociais }\end{array}$ & $\begin{array}{c}\text { Encargos } \\
\text { da } \\
\text { Dívida }\end{array}$ & $\begin{array}{c}\text { Outras } \\
\text { Despesas } \\
\text { Correntes }\end{array}$ & $\begin{array}{c}\text { Investi- } \\
\text { mentos }\end{array}$ & $\begin{array}{c}\text { Inversões } \\
\text { Financeiras }\end{array}$ & $\begin{array}{c}\text { Amortização } \\
\text { da } \\
\text { Dívida }\end{array}$ & TOTAL \\
\hline 1995 & 13.549 & 0,36 & 1.613 & 205 & 0,28 & 0,85 & 15.368 \\
\hline 1996 & 12.095 & - & 1.581 & 270 & 1,07 & - & 13.947 \\
\hline 1997 & 12.043 & - & 1.635 & 148 & 0,21 & - & 13.825 \\
\hline 1998 & 11.876 & - & 1.647 & 11 & - & - & 13.534 \\
\hline 1999 & 12.305 & - & 1.413 & 27 & - & - & 13.745 \\
\hline 2000 & 11.521 & - & 1.344 & 94 & 0,01 & - & 12.959 \\
\hline 2001 & 10.485 & - & 1.292 & 53 & - & - & 11.830 \\
\hline 2002 & 10.996 & - & 1.041 & 42 & 2,45 & 0 & 12.081 \\
\hline 2003 & 9.733 & - & 895 & 51 & 3,69 & 0 & 10.682 \\
\hline 2004 & 10.632 & - & 1.096 & 99 & 0,34 & 0 & 11.828 \\
\hline 2005 & 10.044 & - & 1.200 & 161 & 1,10 & 0 & 11.406 \\
\hline 2006 & 12.663 & - & 1.309 & 180 & - & 0 & 14.152 \\
\hline
\end{tabular}

Fonte: Recursos das IFES: 1995-2006:Execução Orçamentária da União - http://www.camara. gov.br 


\section{Gráfico 01 - Total de recursos das IFES (1995-2006), excluindo-se os recursos próprios}

Valores em R\$ milhões, a preços de janeiro de 2007 (IGP-DI/FGV)

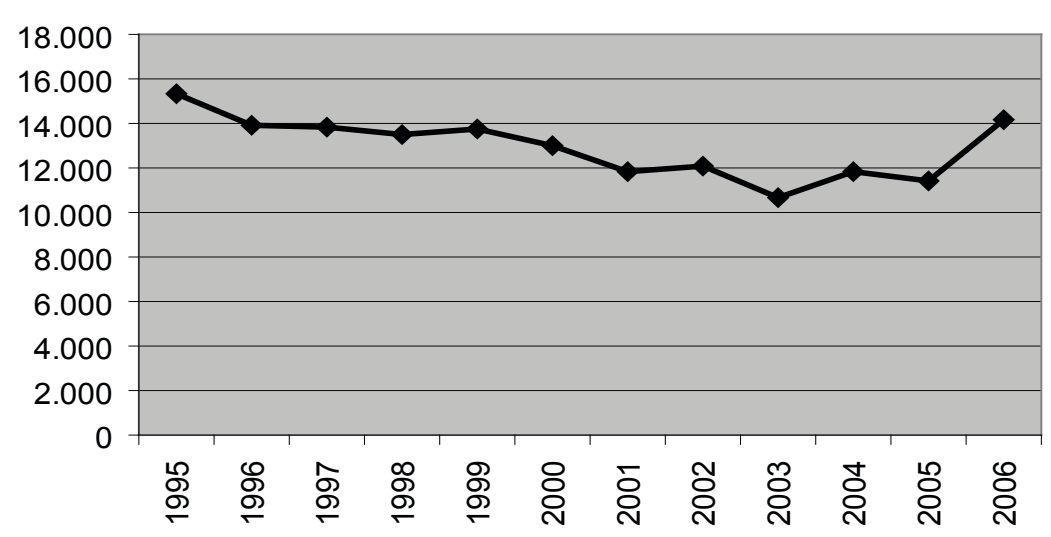

Os valores financeiros destinados aos encargos e amortização da dívida e inversões financeiras são pequenos, quando comparados com os recursos de pessoal, outras despesas correntes e investimentos. Os recursos das IFES se concentraram nos blocos que registram o pagamento de pessoal e encargos sociais, que realizam as outras despesas correntes e no que efetiva as despesas de investimento.

Os recursos alocados no fundo público às IFES, excluindo-se os recursos próprios, tiveram o seu valor mais elevado em 1995, e, como resultado da pressão por redução dos gastos das IFES - o que significaria a redução dos gastos fiscais do Governo Federal -, os valores foram sempre decrescentes, até o ano de 2003. O aumento dos recursos nos anos de 2004 a 2006 reflete a contratação de novos professores e servidores técnico-administrativos e expansão dos campi situados no interior dos Estados. A queda da massa salarial dos trabalhadores das IFES se apresenta, a partir de 1995, como fruto de uma política salarial que não proporcionou reajustes regulares e coibiu a abertura de concursos públicos para as vagas de aposentadoria. A elevação dos recursos de pessoal em 1999 seria devido à implantação da Gratificação de Estímulo à Docência (GED), pela Lei No 9.678, de 3 de julho de 1998.

É necessário dirigir um olhar mais atento para os recursos de pessoal e encargos sociais, outras despesas correntes e investimentos. No montante dos 
recursos gastos com pagamento de pessoal e encargos sociais, estão incluídos os pagamentos de inativos, pensionistas e precatórios; é preciso examinar que volume de recursos se destina ao pagamento daqueles que se encontram em atividade nas instituições. Incluídos nas outras despesas correntes, estão os pagamentos dos chamados "salários indiretos" como vale-transporte, auxílioalimentação, vale-creche etc. Que montante de recursos se destina à efetiva manutenção das instituições? Um exame rápido da Tabela 08, na coluna relativa a investimentos, indica a gravidade da drástica redução dos valores que foram destinados à realização de obras, aquisição de equipamentos, material permanente, livros etc.

No montante de recursos de pessoal e encargos sociais estão incluídos os recursos para pagamento de inativos, pensionistas e precatórios.

O percentual dos gastos com inativos e pensionistas, em relação ao total dos gastos com pessoal, é da ordem de 30\%, o que distorce análises que são realizadas a respeito dos custos das atividades realizadas pelas IFES. $\mathrm{O}$ valor gasto com o pagamento do pessoal em atividade, nas IFES, é, portanto, substancialmente menor que aqueles da tabela 05 . A tabela 06 apresenta os gastos com pessoal quando se subtrai o pagamento de inativos, pensionistas e precatórios:

Tabela 06 - Recursos de pessoal e encargos sociais das IFES retirando-se inativos, pensionistas e precatórios, excluídos os recursos próprios (1995-2006)

Valores em R\$ milhões, a preços de janeiro de 2007(IGP-DI/FGV)

\begin{tabular}{rrrr}
\hline Ano & $\begin{array}{r}\text { Rec.Pessoal e } \\
\text { Enc.Sociais }\end{array}$ & $\begin{array}{r}\text { Inat.Pens. e } \\
\text { Precatórios }\end{array}$ & $\begin{array}{r}\text { Rec.Pessoal } \\
\text { Atividade }\end{array}$ \\
\hline 1995 & 13.549 & 4.300 & 9.249 \\
\hline 1996 & 12.095 & 3.991 & 8.104 \\
\hline 1997 & 12.043 & 4.530 & 7.513 \\
\hline 1998 & 11.876 & 4.597 & 7.279 \\
\hline 1999 & 12.305 & 4.458 & 7.847 \\
\hline 2000 & 11.521 & 4.111 & 7.410 \\
\hline 2001 & 10.485 & 3.759 & 6.726 \\
\hline 2002 & 10.996 & 3.925 & 7.070 \\
\hline 2003 & 9.733 & 4.299 & 6.433 \\
\hline 2004 & 10.632 & 4.045 & 6.587 \\
\hline 2005 & 10.044 & 3.878 & 8.318 \\
\hline 2006 & 12.663 & 4.345 & \\
\hline
\end{tabular}

Fonte: Execução Orçamentária da União de 1995 a 2006 - http://www.camara.gov.br

O Gráfico 02 apresenta a evolução dos gastos com o pessoal em atividade: 
Gráfico 02 - Recursos de Pessoal e Encargos Sociais das IFES retirando-se Inativos, Pensionistas e Precatórios (1995-2006)

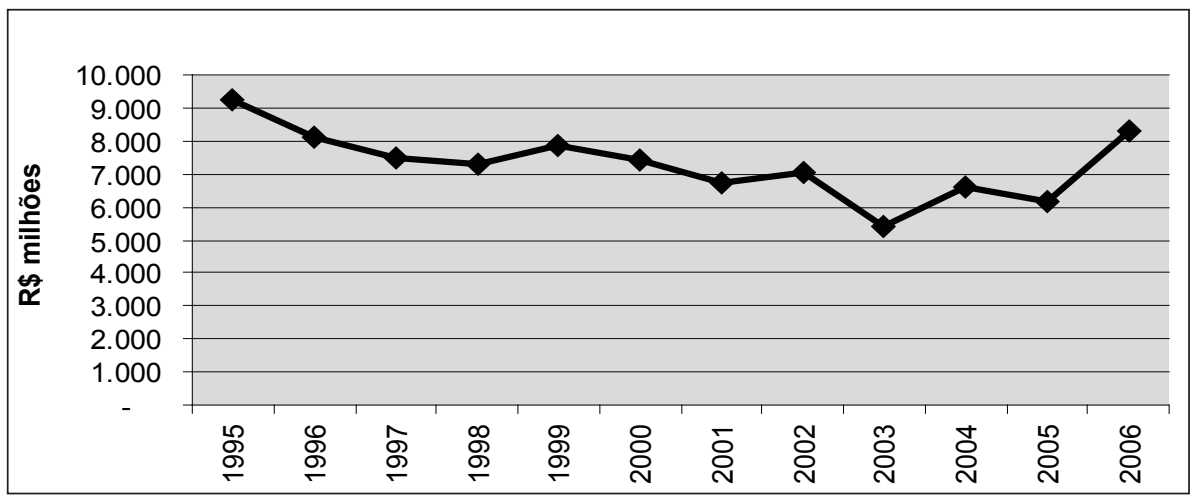

Explicita-se, portanto, um resultado claramente decrescente, de 1995 a 2003 para os recursos de pessoal e encargos sociais das IFES, quando se retiram os gastos com inativos, pensionistas e precatórios.

As outras despesas correntes são aquelas que se destinam à aquisição de material de consumo para os laboratórios, pagamento de água, luz, telefone, fotocópias, pagamento de serviços de terceiros, pagamento de professores substitutos (a partir de 1997) e etc. Nesse período, os gastos das IFES com esses itens foram os da tabela 07 e gráfico 03:

Tabela 07 - Recursos de outras despesas correntes das IFES, excluindo-se os recursos próprios (1995-2006)

Valores em R \$ milhões, a preços de janeiro de 2007 (IGP-DI/FGV)

\begin{tabular}{lc}
\hline Ano & Recursos de Outras Despesas Correntes \\
\hline 1995 & 1.613 \\
\hline 1996 & 1.581 \\
\hline 1997 & 1.635 \\
\hline 1998 & 1.647 \\
\hline 1999 & 1.413 \\
\hline 2000 & 1.344 \\
\hline 2001 & 1.292 \\
\hline 2002 & 1.041 \\
\hline 2003 & 895 \\
\hline 2004 & 1.096 \\
\hline 2006 & 1.200 \\
\hline
\end{tabular}

Fonte: Execução Orçamentária da União de 1995 a 2006 - http://www.camara.gov.br 
Gráfico 03 - Recursos de outras despesas correntes das IFES, excluídos os recursos próprios (1995-2006)

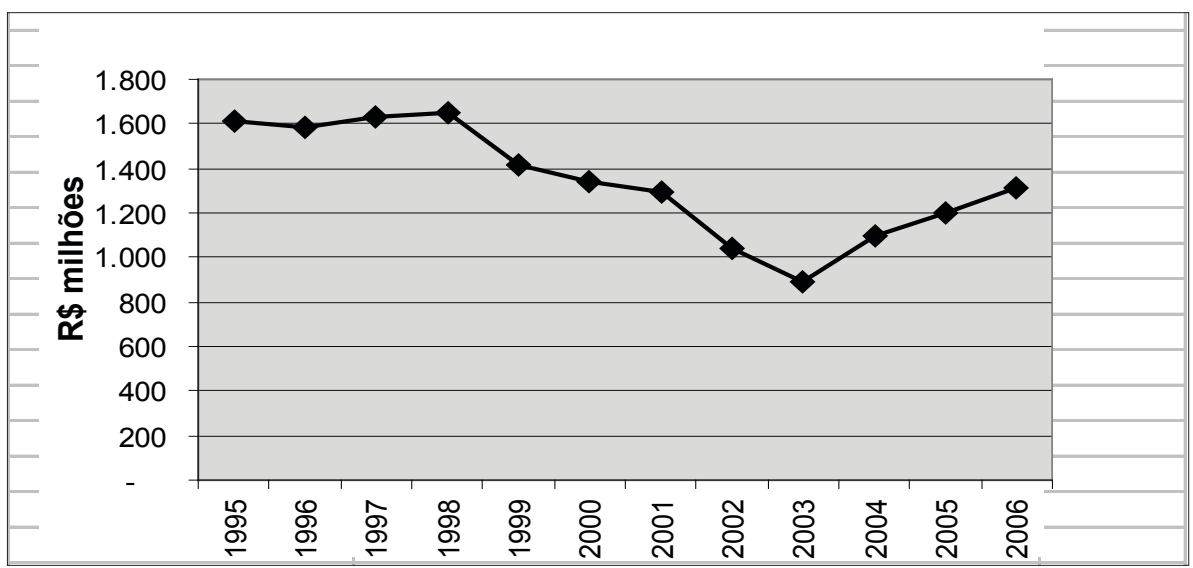

Esses recursos permaneceram praticamente inalterados de 1995 a 1998, sofrendo quedas sucessivas de 1999 a 2003, o que provoca uma diminuição nas condições de as instituições elaborarem novos projetos e implementá-los sem a presença de recursos de fontes oriundas do setor privado, o que exige a presença do serviço das fundações de apoio na gerência desses recursos.

Quando comparamos os valores de outras despesas correntes do período 1990 a 1994 - valores que flutuaram entre R $\$ 767$ milhões e R \$ 1.174 milhões -, com os valores do período 1995-2003 - valores entre R\$ 1.613 milhões e R \$ 895 milhões -, poderíamos ser levados a concluir que houve, num determinado período, uma elevação substancial nos recursos que se dirigiram para a modernização de laboratórios, aquisição de livros, construção de novas salas de aulas, aquisição de reagentes químicos para os laboratórios etc. Entretanto, nada disso ocorreu, como pode se verifica a seguir.

No contexto dos gastos de outras despesas correntes e investimentos, encontram-se, além daqueles que se destinam diretamente às finalidades acadêmicas, os chamados "salários indiretos" que são: vale-transporte, auxílio-alimentação, assistência médica e odontológica a servidores e seus dependentes, apoio à educação das crianças de 0 a 6 anos - chamado de vale-creche -, e o PASEP, formação do Patrimônio do Servidor Público. São itens de despesas que se caracterizam como benefícios aos servidores, muito deles implantados para ame- 
nizar a falta de reajustes salariais lineares. Além desses, são considerados como recursos de outras despesas correntes o pagamento de professores substitutos e o pagamento de médicos residentes. Os professores substitutos deveriam ser pagos com recursos de pessoal, o que ocorreu até 1996, alterando-se, a partir de 1997, para recursos de outras despesas correntes. O pagamento dos médicos residentes poderiam ser caracterizados como bolsas-salário. A contratação de professores substitutos se fez necessária pela proibição de abertura de novos concursos públicos para a vaga dos professores que se aposentaram.

A efetiva manutenção das instituições é, portanto, realizada com os recursos resultantes da subtração de todos os valores associados a essas atividades. A tabela 08 mostra os valores que resultaram para esse fim. O gráfico 04 mostra o total de recursos para a efetiva manutenção das IFES.

Tabela 08 - Recursos para efetiva manutenção das IFES (1995-2006), excluindo-se recursos diretamente arrecadados

Valores em R \$ milhões, a preços de janeiro de 2007 (IGP-DI/FGV)

\begin{tabular}{lccccccc}
\hline Ano & Rec. de Outras & Benefícios & Pasep & Prof. & Res. & Ass.Méd. & Efetiva \\
\hline & Desp. e Investimentos & a Servidores* & & Subst. & Méd. & Odon.Ser. & Manuten. \\
\hline 1995 & 1.818 & 634 & 33 & - & 131 & 2,1 & 1.017 \\
\hline 1996 & 1.852 & 563 & 33 & - & 124 & 15,1 & 1.116 \\
\hline 1997 & 1.783 & 511 & 16 & 160 & 128 & 11,0 & 956 \\
\hline 1998 & 1.658 & 458 & - & 244 & 117 & 4,0 & 835 \\
\hline 1999 & 1.440 & 406 & 0,2 & 169 & 97 & - & 767 \\
\hline 2000 & 1.438 & 361 & - & 143 & 99 & 0,1 & 836 \\
\hline 2001 & 1.345 & 374 & - & 159 & - & 0,3 & 812 \\
\hline 2002 & 1.083 & 305 & - & 166 & 119 & 0,2 & 494 \\
\hline 2003 & 946 & 283 & - & 141 & 105 & 0,1 & 417 \\
\hline 2004 & 1.195 & 343 & - & 147 & 97 & 0,2 & 608 \\
\hline 2005 & 1.361 & 332 & - & 152 & 95 & 0,2 & 782 \\
\hline 2006 & 1.488 & 331 & - & 165 & 64 & 0,1 & 928 \\
\hline
\end{tabular}

Fonte: Execução Orçamentária da União de 1995 a 2001 - http://www.camara.gov.br

Orçamentária da União de 1995 a 2006 - http://www.camara.gov.br

* Vale-Transporte, Auxílio-Alimentação e Vale-Creche 
Gráfico 04 - Total de recursos para efetiva manutenção das IFES (19952006), excluindo-se recursos diretamente arrecadados.

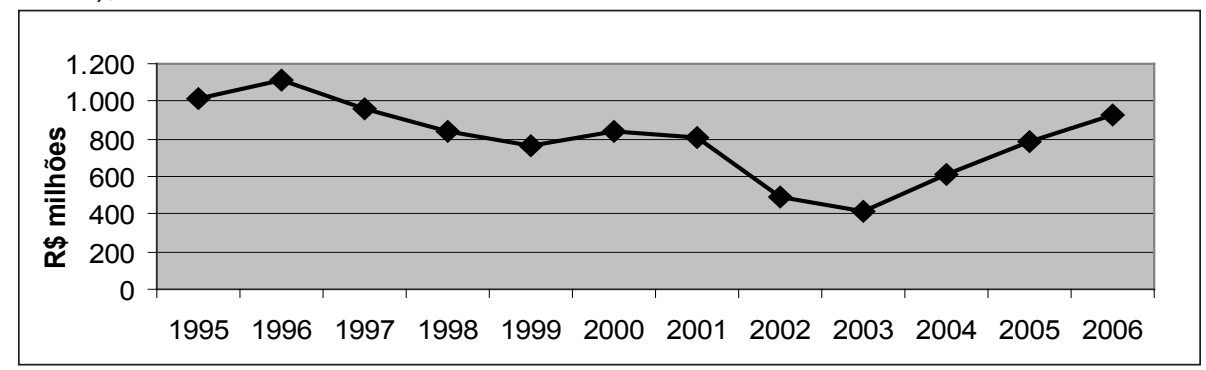

Houve uma redução substancial nos recursos para a efetiva manutenção das instituições no período de 1995 a 2003. A implantação dos diversos benefícios ocorreu a partir de 1994 e, a partir de 1995, os reajustes lineares dos servidores públicos foram praticamente desativados. Os benefícios, portanto, passaram a atuar como "salários indiretos". A drástica redução nesses recursos pode ser aquilatada verificando-se que em 1990 eles significavam 92,1\% dos recursos de outras despesas correntes e investimentos e, em 2002, apenas 48\% desses recursos (AMARAL, 2003).

Os recursos de investimentos se aplicam à aquisição de equipamentos, mobiliário, material bibliográfico, obras físicas etc. Esses recursos, excluídos os diretamente arrecadados pelas instituições, consta da tabela 09 e do gráfico 05.

Tabela 09 - Recursos de investimentos das IFES, excluindo-se os recursos próprios (1995-2006)

\begin{tabular}{cc} 
Valores em $\mathrm{R} \$$ milhões, a preços de janeiro de 2007 (IGP-DI/FGV) \\
\hline Ano & Investimentos \\
\hline 1995 & 205 \\
\hline 1996 & 270 \\
\hline 1997 & 148 \\
\hline 1998 & 11 \\
\hline 1999 & 27 \\
\hline 2000 & 94 \\
\hline 2001 & 53 \\
\hline 2002 & 42 \\
\hline 2003 & 51 \\
\hline 2004 & 99 \\
\hline 2005 & 161 \\
\hline 2006 & 180 \\
\hline
\end{tabular}

Fonte: Execução Orçamentária da União de 1995 a 2006 - http://www.camara.gov.br 
Gráfico 05 Recursos de investimentos das IFES, excluindo-se os recursos próprios (1995-2006)

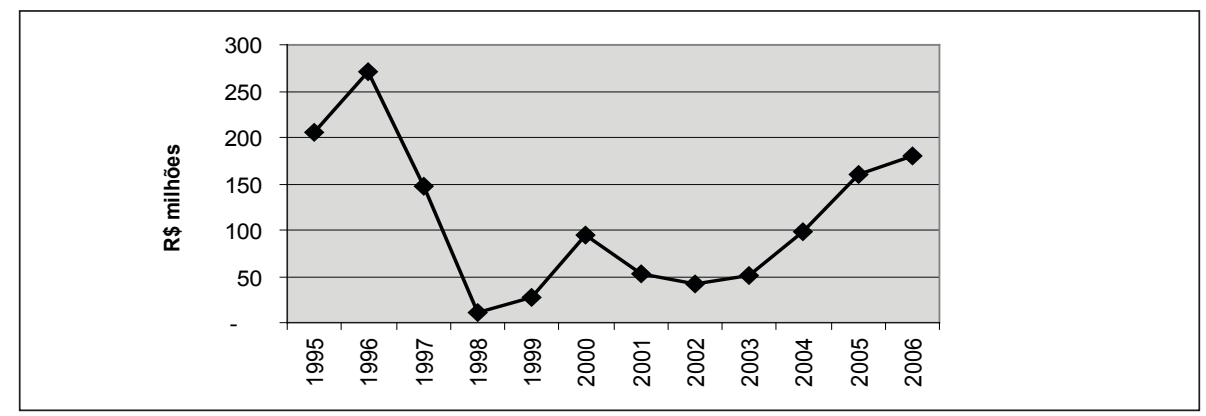

O Gráfico 05 explicita a drástica redução ocorrida no período. Comparandose 1996 com 2002, pode-se afirmar que eles se reduziram a 1/13 e, nos anos de 1998 e 1999, foram quase nulos, quando comparados com os de 1996.

Utilizando-se dos recursos próprios, aqueles arrecadados pela prestação de serviços, assessorias, consultorias, cursos, aplicação no mercado financeiro etc., as seguintes despesas foram realizadas pelas IFES, de 1995 a 2006 (tabela 10 e gráfico 06):

Tabela 10 - Recursos das IFES (1995-2006), originários da arrecadação própria

Valores em R \$ milhões, a preços de janeiro de 2007 (IGP-DI/FGV)

\begin{tabular}{rccccccr}
\hline Ano & $\begin{array}{c}\text { Pessoal e } \\
\text { Encargos } \\
\text { Sociais }\end{array}$ & $\begin{array}{c}\text { Encargos } \\
\text { da } \\
\text { Dívida }\end{array}$ & $\begin{array}{c}\text { Outras } \\
\text { Despesas } \\
\text { Correntes }\end{array}$ & $\begin{array}{c}\text { Investi- } \\
\text { mentos }\end{array}$ & $\begin{array}{c}\text { Inversões } \\
\text { Financeiras }\end{array}$ & $\begin{array}{c}\text { Amortização } \\
\text { da } \\
\text { Dívida }\end{array}$ & TOTAL \\
\hline 1995 & 20,1 & 3,4 & 975 & 343 & 8,49 & 1,8 & 1.353 \\
\hline 1996 & - & 4,6 & 1.050 & 62 & 1,09 & 1,9 & 1.120 \\
\hline 1997 & - & 2,4 & 862 & 107 & 0,18 & 4,6 & 976 \\
\hline 1998 & 6,9 & 1,5 & 899 & 98 & 0,07 & 1,6 & 1.007 \\
\hline 1999 & - & - & 403 & 84 & 0,15 & - & 488 \\
\hline 2000 & - & - & 390 & 67 & 0,22 & - & 457 \\
\hline 2001 & - & - & 371 & 76 & 0,15 & - & 447 \\
\hline 2002 & - & - & 358 & 44 & 0,13 & - & 402 \\
\hline 2003 & - & - & 339 & 59 & 0,09 & - & 398 \\
\hline 2004 & - & - & 387 & 50 & 0,06 & - & 437 \\
\hline 2005 & 0 & 0 & 398 & 61 & 0,08 & 0 & 460 \\
\hline 2006 & 0 & 0 & 477 & 77 & 0 & 0 & 555 \\
\hline
\end{tabular}

Fonte: Recursos das IFES: 1995-2006:Execução Orçamentária da União - http://www.camara.gov.br Desp. Correntes do FPF: Execução Orçamentária do Governo Federal e Balanço Geral da União. 
Gráfico 06 - Total de recursos das IFES (1995-2006), originários da arrecadação própria

Valores em R \$ milhões, a preços de janeiro de 2007 (IGP-DI/FGV)

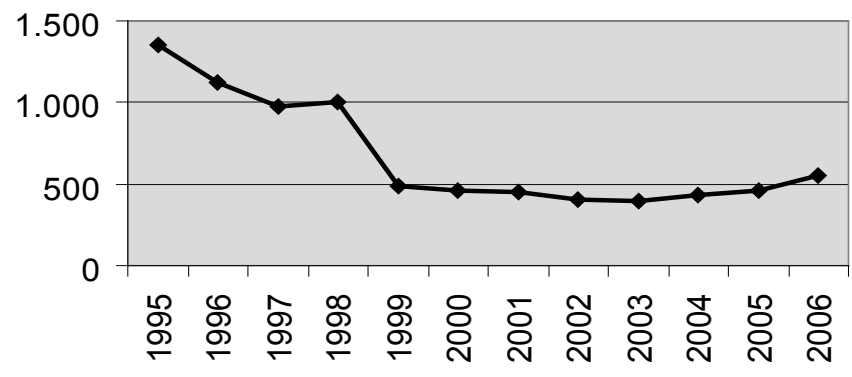

Os recursos próprios se dirigiram, prioritariamente, para o pagamento de outras despesas correntes e investimentos. Algumas instituições aplicaram recursos próprios em pagamento de pessoal e encargos sociais, encargos das dívidas, inversões financeiras e amortização de dívidas - pequenos valores se comparados aos de outras despesas correntes e investimentos.

Sobre os recursos próprios temos ainda a observar que a partir de 1995 houve uma "corrida" das IFES em direção às fundações de apoio, utilizandoas como veículo de "interlocução" entre as instituições e o mercado e que de alguma forma acentuam sua inserção no chamado quase-mercado educacional. A evolução do número de fundações credenciadas pelo MEC e pelo MCT, para atuarem conjuntamente com as IFES, credenciamento previsto na Lei 8.958, de 1994, nos dá uma idéia dessa "corrida": em 1995 estavam credenciadas 42 fundações de apoio; em 1996, 52 fundações; em 1997, 61 fundações; em 1998, 68 fundações; em 1999, 79 fundações; em 2000, 88 fundações; e em 2001, 96 fundações de apoio às IFES. Houve, portanto, de 1995 para 2001, um crescimento de $129 \%$ no número de fundações de apoio credenciadas pelo MEC e MCT. São fundações de apoio com as mais variadas vinculações institucionais e que servem a objetivos os mais diversos (AMARAL, 2003).

Três indicadores da riqueza nacional, o Produto Interno Bruto, as despesas correntes do fundo público federal e o total de arrecadação de impostos da União, permitem avaliar o que representou o financiamento das IFES no contexto da riqueza brasileira. A tabela 11 e os gráficos 07, 08 e 09 apresentam os recursos das IFES como percentual desses indicadores:

Os recursos, em relação ao PIB, caíram de $0,97 \%$, em 1989 , para $0,62 \%$, em 2006; em relação às despesas correntes do fundo público federal, caíram de 
5,91\%, em 1989, para 2,85\%, em 2006; e em relação à arrecadação de impostos da União, caíram de 12,5\%, em 1989, para 7,8\%, em 2006.

Há, portanto, em relação à riqueza nacional, uma crônica redução dos recursos financeiros aplicados nas instituições federais de ensino superior brasileiras, o que está comprometendo o desenvolvimento dessas instituições, diminuindo a capacidade que elas possuem de intervenção na realidade do País, tornando-as obsoletas frente às inovações tecnológicas e mostrando que existe uma despreocupação de governantes, tanto do poder executivo quanto do poder legislativo, com relação a instituições que são fundamentais para a manutenção da soberania Nacional.

Tabela 11 - Recursos das IFES como percentual do PIB, das Despesas Correntes do FPF e da arrecadação de impostos da União

Valores em R\$ milhões, a preços de janeiro de 2007 (IGP-DI/FGV)

\begin{tabular}{cccccccc}
\hline Ano & \multirow{2}{*}{ PIB } & Despesas & IMPOSTOS & \multicolumn{3}{c}{ IFES } \\
\cline { 6 - 8 } & & & $\begin{array}{c}\text { Correntes } \\
\text { do FPF }\end{array}$ & Recursos & \%PIB & \%FPF & \% Impostos \\
\hline 1989 & 1.756 .061 .009 & 287.880 & 136.388 & 17.027 & 0,97 & 5,91 & 12,5 \\
\hline 1990 & 1.757 .030 .199 & 286.686 & 168.568 & 13.859 & 0,79 & 4,83 & 8,2 \\
\hline 1991 & 1.785 .794 .719 & 208.378 & 117.419 & 10.908 & 0,61 & 5,23 & 9,3 \\
\hline 1992 & 1.740 .201 .792 & 230.359 & 70.937 & 9.861 & 0,57 & 4,28 & 13,9 \\
\hline 1993 & 1.736 .955 .061 & 295.912 & 130.102 & 12.807 & 0,74 & 4,33 & 9,8 \\
\hline 1994 & 1.716 .357 .111 & 285.966 & 173.764 & 15.573 & 0,91 & 5,45 & 9,0 \\
\hline 1995 & 2.071 .126 .370 & 326.762 & 149.282 & 16.700 & 0,81 & 5,11 & 11,2 \\
\hline 1996 & 2.229 .733 .565 & 337.549 & 149.390 & 15.067 & 0,68 & 4,46 & 10,1 \\
\hline 1997 & 2.299 .278 .708 & 346.165 & 152.997 & 14.802 & 0,64 & 4,28 & 9,7 \\
\hline 1998 & 2.307 .815 .657 & 381.385 & 170.702 & 14.534 & 0,63 & 3,81 & 8,5 \\
\hline 1999 & 2.254 .630 .092 & 394.647 & 171.657 & 14.232 & 0,63 & 3,61 & 8,3 \\
\hline 2000 & 2.194 .743 .789 & 369.225 & 156.565 & 13.416 & 0,61 & 3,63 & 8,6 \\
\hline 2001 & 2.195 .491 .997 & 394.346 & 163.994 & 12.277 & 0,56 & 3,11 & 7,5 \\
\hline 2002 & 2.195 .253 .919 & 389.950 & 175.044 & 12.484 & 0,57 & 3,20 & 7,1 \\
\hline 2003 & 2.056 .406 .744 & 367.411 & 151.908 & 11.080 & 0,54 & 3,02 & 7,3 \\
\hline 2004 & 2.146 .770 .261 & 384.103 & 155.209 & 12.264 & 0,57 & 3,19 & 7,9 \\
\hline 2005 & 2.241 .336 .605 & 418.252 & 173.692 & 11.865 & 0,53 & 2,84 & 6,8 \\
\hline 2006 & 2.382 .711 .481 & 516778 & 187.441 & 14.706 & 0,62 & 2,85 & 7,8 \\
\hline
\end{tabular}

Fonte:PIB:Banco Central do Brasil e IPEA - http://www.ipeadata.gov.br; Impostos: Arrecadação da Receita Administrada pela SRF. http://www.receita.fazenda.gov.br; Recursos das IFES: 19891994:MF/STN/CGC; 1995-2006:Execução Orçamentária da União - http://www.camara.gov.br Desp. Correntes do FPF: Execução Orçamentária do Governo Federal e Balanço Geral da União. 
Gráfico 07 - Total de recursos das IFES, todas as fontes, como percentual do PIB

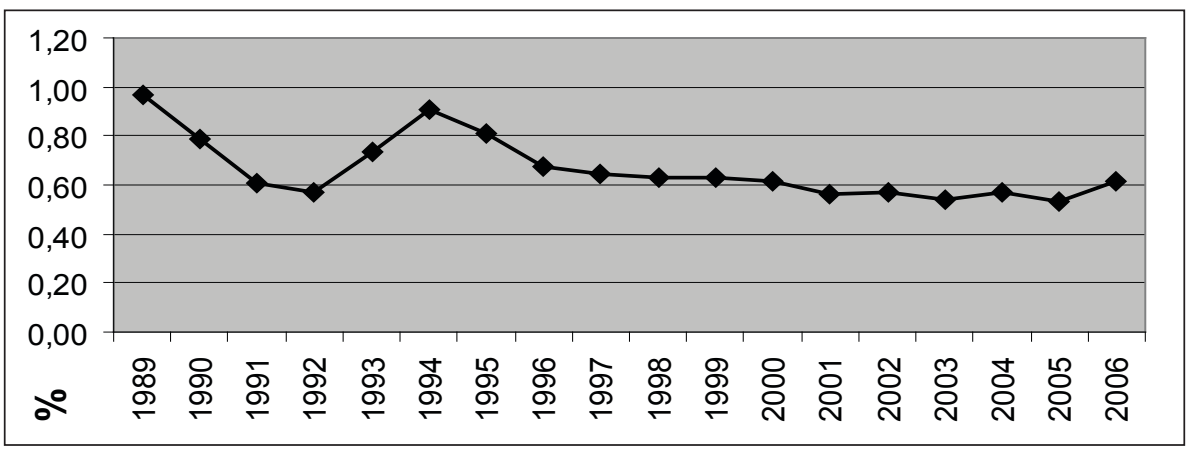

Gráfico 08- Total de recursos das IFES, todas as fontes, como percentual das Despesas Correntes do FPF

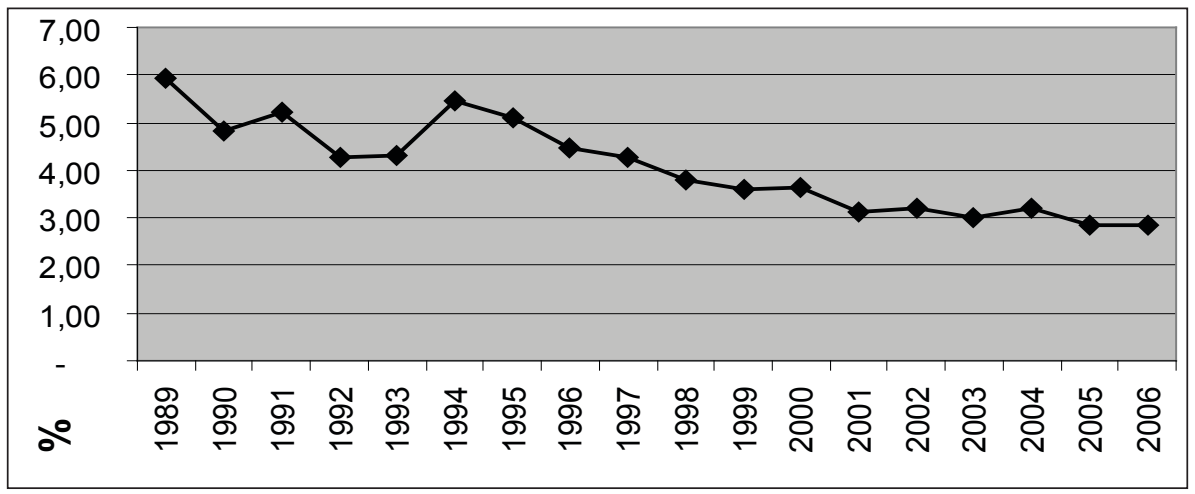

Gráfico 09 - Total de recursos das IFES, todas as fontes, como percentual dos impostos

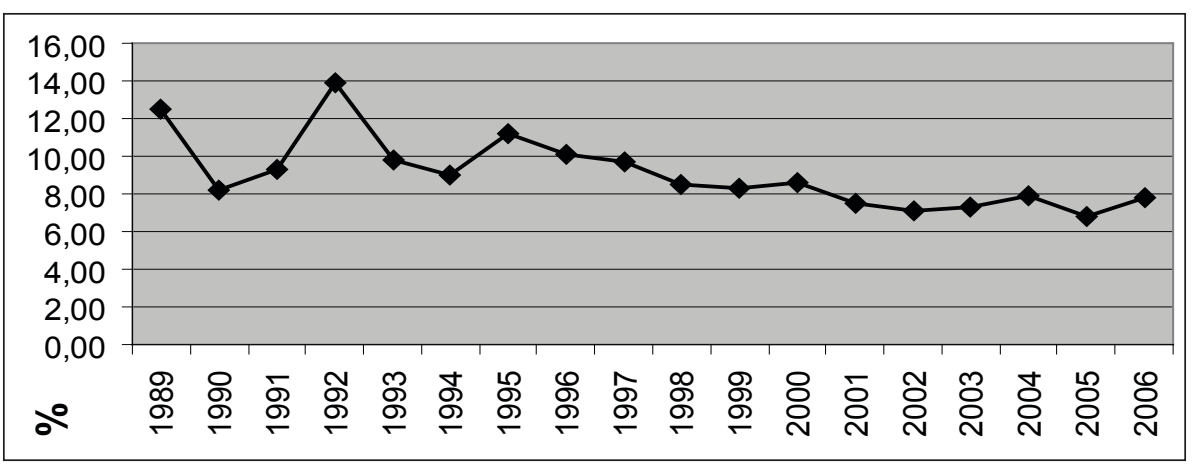




\section{Considerações Finais: Desafios e Ações}

São grandes, portanto, os desafios para se compreender a situação das IFES, bem como para definir uma política que estabeleça diretrizes e ações que garantam a manutenção e o desenvolvimento institucional, tendo por base a natureza dessas instituições, as necessidades concretas do país e a efetivação da autonomia universitária, conforme estabelece a Constituição Federal de 1998.

O papel a ser desempenhado, no contexto nacional, pelo conjunto das IFES precisa ser minimamente acordado entre a sociedade, governantes e instituições. Nessa formulação, é preciso responder às seguintes indagações:

a) como potencializar ainda mais a contribuição das IFES, visando diminuir as desigualdades regionais?

b) que colaboração mais direta poderia ser estabelecida entre as instituições para, também, diminuir a heterogeneidade existente entre elas?

c) como alcançar um desejado equilíbrio entre a função cultural e a "função utilitarista"?

d) como manter um controle sobre a chegada ao quase-mercado educacional?

e) como controlar a presença das fundações de apoio e que recursos elas deveriam gerenciar?

A implementação de uma verdadeira autonomia exige a definição clara do montante de recursos a ser distribuído entre as instituições. Nesse sentido, faz-se necessário discutir em profundidade:

a) quais fontes deveriam ser utilizadas para a obtenção desse montante de recursos? Um percentual dos impostos? Um percentual do PIB? Um percentual das despesas correntes do fundo público federal?

b) como dividir o montante de recursos entre as instituições? Deveriam ser utilizadas fórmulas contendo indicadores quantitativos e qualitativos? Como definir indicadores qualitativos?

É preciso estabelecer o melhor caminho, nesse momento, para esse importante conjunto de instituições brasileiras e abandonarmos a idéia já latente em muitas instâncias, inclusive dentro da própria instituição, de que a trajetória atualmente seguida é inevitável e que elas tendem a sucumbir e a diminuir sua importância para a formação de profissionais, para a geração de conhecimento e para o desenvolvimento científico, tecnológico e cultural da Nação.

Há, portanto, muitas indefinições e problemas a resolver. 
As regras para o financiamento das IFES poderiam se dar num diálogo entre Governo e Instituições até que a execução orçamentária anual das IFES ultrapassasse o limite histórico de 1\% do PIB.

No contexto desse aumento deveriam ser elaborados planos de desenvolvimento institucionais (PDI). Este, ao ser discutido com a participação e o envolvimento daqueles que o executarão, sem imposição de metas a serem alcançadas, constitui-se em um valioso instrumento da gestão universitária, por estabelecer princípios, diretrizes, metas e responsabilidades a serem alcançadas, colaborando para que os rumos estabelecidos, em cada instituição, sejam perseguidos por todos que possuem responsabilidade em sua execução.

A autonomia das IFES não se efetivou desde 1988, após a nova Constituição Federal, uma vez que elas continuam a depender integralmente das definições orçamentárias estabelecidas pelo Poder Executivo e aprovadas pelo Congresso Nacional na formulação do financiamento incremental ou inercial. Tal situação impõe a necessidade de garantir uma efetiva autonomia, o que implica em mudanças significativas no padrão de financiamento. Nesse cenário, a desmercantilização das IES públicas e das IFES, em particular, constitui-se imperativo nas opções a serem estabelecidas para a utilização do Fundo Público. Faz-se necessário também demarcar, de maneira mais clara, como o país vai utilizar e distribuir a riqueza pública produzida e como vai estabelecer as formas de controle institucionais desses recursos, sobretudo se compreendermos a universidade como uma instituição social, científica e educativa, cuja identidade está fundada em princípios, valores, regras e formas de organização que the são inerentes.

\section{Referências}

AMARAL, Nelson C. Financiamento da educação superior: estado $x$ mercado. São Paulo: Cortez; Unimep, 2003.

ASSOCIAÇÃO NACIONAL DOS DIRIGENTES DAS INSTITUIÇÕES DE ENSINO SUPERIOR (ANDIFES). ALGUMAS OBSERVAÇÕES SOBRE A AUTONOMIA UNIVERSITÁRIA. Documento para discussão pela ANDIFES. Brasília, 1992. Mimeografado.

\section{MATRIZ DE ALOCAÇÃO DE RECURSOS PARA AS IFES.}

Documento da Associação Nacional de Dirigentes das Instituições Federais de Ensino Superior. Brasília, 1994. 
. LEI ORGÂNICA DAS UNIVERSIDADES. Documento da Associação Nacional de Dirigentes de Instituições Federais de Ensino Superior. Brasília, 1996.

. PROPOSTA DE EXPANSÃO E MODERNIZAÇÃO DO SISTEMA PÚBLICO FEDERAL DE ENSINO SUPERIOR. Documento da Associação Nacional de Dirigentes de Instituições Federais de Ensino Superior. Brasília, 2003.

BARACHO, José A. de Oliveira. Autonomia Universitária: questões constitucionais e legais à autoaplicabilidade. Parecer fornecido à ANDIFES. Brasília, 1996. Mimeografado.

BERCHEM, Theodor. A missão das universidades na formação e no desenvolvimento culturais: a diversidade dentro da universalidade. In: $A$ missão da universidade hoje. Cadernos Plurais, 5, série Universidade-I. Rio de Janeiro: Gráfica da UERJ, 1990.

BANCO INTERNACIONAL PARA RECONSTRUÇÃO E O DESENVOLVIMENTO (BIRD). La enseñanza superior: las lecciones derivadas de la experiencia. Washington-DC: Banco Mundial, 1995. Primeira Edição em Espanhol.

BRASIL. MEC. A política para as instituições federais de ensino superior. Brasília, 1995. (Mimeografado).

. PNAD/IBGE. Pesquisa Nacional por Amostra de DomicílioPNAD. Brasília, 2007. Disponível em : <http:// www.ibge.gov.br >. Acesso em: 10 nov. 2007.

. PNE. Plano Nacional de Educação. Lei no 10.172/2001 (PNE).

Brasília: Congresso Nacional, 2001.

CONCEIÇÃO, Pedro et al. Novas idéias para a universidade. Lisboa: IST Press, 1998.

CONSELHO DE REITORES /UNIVERSIDADES BRASILEIRAS (CRUB). Universidade, autonomia, qualidade e compromisso social. REUNIÃO PLENÁRIA DO CRUB, 55, 1992, Salvador. [Anais...]. Salvador, 1992. Mimeografado.

FÁVERO, Maria de Lourdes. A universidade do Brasil: das origens à 
construção. Rio de Janeiro: Editora UFRJ, 2000.

JONGBLOES, B.; MAASSEN, P. Funding of higher education in developing countries. In: CONFERÊNCIA INTERNACIONAL DO PROGRAMA ALFA-BRACARA, na UNAM, 1999, Cidade do México. [Anais...]. Cidade do México, 1999. Mimeografado.

NERI, Marcelo. Real não diminuiu desigualdades. Conjuntura Econômica, Rio de Janeiro, jul. 2000.

SGUISSARDI, Valdemar. Universidade, fundação e autoritarismo: o caso da UFSCar. São Carlos-SP: UFSCar; São Paulo: Estação Liberdade, 1993. (Relatório da CPI do Ensino Superior, DCN, 29 de novembro de 1969, Suplemento $2^{\circ} 26 \mathrm{~m}$, p.1-406).

SOUSA SANTOS, Boaventura. Pela mão de Alice: o social e o político na pós-modernidade. 6. ed. São Paulo: Cortez, 1999.

TÜNNERMANN BERNHEIM, Carlos. Una nueva visión de la educación superior. Revista Educación Superior y Sociedad, Caracas-Venezuela, v. 6, n. 1, p.123-136, 1995.

UNIÓN DE UNIVERSIDADES DA AMÉRICA LATINA Y EL CARIBE (UDUAL). La universidad latinoamericana en el fin de siglo: realidades y futuro. México, DF: UDUAL, 1995.

UNESCO; CRUB. Tendências da educação superior para o século XXI. In: CONFERÊNCIA MUNDIAL SOBRE O ENSINO SUPERIOR, 1998, Paris. [Anais...]. Brasília-DF: [s. n.], 1999.

UNESCO. Documento de política para a mudança e o desenvolvimento na educação superior. Revista Educação Brasileira, Brasília, v. 17, n. 34, p. 153-221, jan./jun. 1995.

VELLOSO, Jacques. Universidade na América Latina: rumos do financiamento. Cadernos de Pesquisa, São Paulo, n. 110, p. 39-66, jul. 2000. 